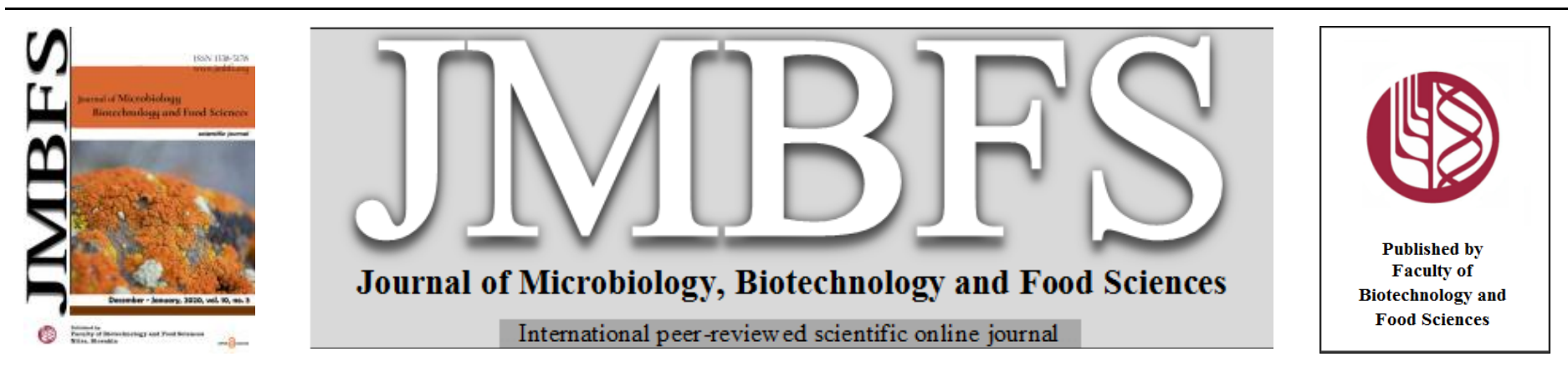

\title{
ELICITATION OF PLANT DEFENSE AGAINST FUSARIUM OXYSPORUM F.SP. CICERIS IN CHICKPEA PLANT USING MARINE MICROCOCCUS SP.
}

\author{
Palak Patel ${ }^{1}$, Keyur Patel ${ }^{1}$, Pinakin Dhandhukia ${ }^{2}$ and Janki N. Thakker ${ }^{* 1}$
}

Address(es):

${ }^{1}$ Department of Biotechnology, P.D. Patel Institute of Applied Sciences, Charotar University of Science and Technology, CHARUSAT Campus, Changa-388421, Anand (Gujarat), India.

${ }^{2}$ Department of Microbiology, Sheth P T Mahila College of Arts and Home Science, Veer Narmad South Gujarat University, Athwa Gate, Surat, Gujarat 395001.

*Corresponding author: jankithakker.bt@ charusat.ac.in

doi: 10.15414/jmbfs.2020.10.3.361-365

ARTICLE INFO

Received 19. 4. 2020

Revised 7. 7. 2020

Accepted 8. 7. 2020

Published 1. 12. 2020

Regular article OPEN $\partial_{\text {ACCESS }}$

\begin{abstract}
Chickpea is produced as well as consumed highest in India amongst the whole world but, production is seriously curtailed by Fusarium wilt, caused by Fusarium oxysporum f.sp. ciceris (FOC). In stressful conditions, the reactive oxygen species (ROS) production increases in plants which cause significant damage. To reduce this ROS, plants have inbuilt antioxidants that can detoxify ROS and protect cells of plants. The present study aimed to investigate the effect of Micrococcus luteus on the induction of defense enzymes in the presence and absence of Fusarium in chickpea. Talc-based bio-formulation of marine M. luteus was employed under pot trials to scrutinize mechanism of induced resistance against Fusarium by the improvement of defense enzymes like SOD, POX as well as accumulation of L-proline, total phenolic and pigments like chlorophyll and carotenoids. Pot trials were done using four different conditions- T1 (control), T2 (M. luteus treated), T3 (FOC treated), and T4 (M. luteus + FOC treated). Defense enzymes were studied and a maximum increase in M. luteus treated plants as compared to control and pathogen treated plants were noted. The chlorophyll and carotenoid content were improved in M. luteus treated plants to pathogen treated plants. This study indicated that M. luteus helps the plant to protect itself from free radicals as it showed significant induction of enhanced plant defense response against soil-borne pathogen to protect chickpea plant.
\end{abstract}

Keywords: L-proline, total phenolic compounds, superoxide dismutase, peroxidase, chlorophyll, carotenoid

\section{INTRODUCTION}

Chickpea (Cicer arietinum L.) is one of the major legume crops widely cultivated for its edible seeds in the Indian sub-continent. Garbanzo beans are mainly used by humans and are an essential constituent of the Mediterranean diet. Seeds provide a decent and economical source of protein for essentially the vegetarian population, by choice or economic reasons, of developing countries especially in South Asia (Gaur et al., 2012). This plant has a significant role in agriculture but the overall crop productivity is sternly hampered by the incursion of soil-borne pathogens such as fungi, bacteria, and viruses. The first report of a soil-borne pathogenic fungus Fusarium oxysporum f.sp.ciceris (FOC) as a causative agent of Fusarium wilt in India and its correct etiology was determined by Butler in 1918 and Padwik in 1940, respectively (Cunnington et al., 2007). Fusarium wilt considered a major exotic disease-causing wilting at any time from the seedling stage to podding. The fungus invades plant root through wounds, assault cortical region, and reach to the stele resulted in characteristic vascular wilt (Singha $\boldsymbol{e t}$ al., 2011). Wilt in chickpea occurs in 32 countries across 6 continents (Singh $\boldsymbol{e t}$ al., 2014).

In response to the cross-talk between plant and pathogen, plants trigger a substantial array of defense mechanisms to ward off pathogens. A most decisive factor imparting successful warding of the pathogen is the swiftness of their defense response initiation which requires an apparent conception of the plant's ability to comprehend pathogen attack and control the expression of defense mechanisms. When plants are exposed to any biotic or abiotic stressful condition, the reactive oxygen species (ROS) production increases and it causes significant damage to the cellular components of plants. Plants have several inbuilt antioxidants that can detoxify ROS and inturn protect cellular components. Assorted defense-related genes chiefly encoding pathogenesisrelated (PR) proteins are present in plants, bestow resistance from pathogens attributed to their potential to ward off pathogens. Therefore, the resistance mechanism of the host can be scrutinized by measuring the alteration in defenserelated marker enzymes in response to external stimuli such as biotic and abiotic factors (Kavino et al., 2009).
The simulated response of plants is often complemented by the production of an array of host proteins with the ability to mount a defense against invader (Tahsili et al., 2014). Research on the elucidation of host defensive responses to pathogen invasion have determined catalase, superoxide dismutase (SOD), peroxidase (POX), polyphenol oxidase (PPO), phenylalanine ammonia-lyase (PAL) and "pathogenesis-related" (PR) proteins (Swarupa et al., 2014 and Dehgahi et al., 2015). A multifaceted association of diverse signals regulates the plant's response for protection against pathogens (Datta and Lal, 2018). The number of chemical fungicides adopted to control fungal pathogens for a prolonged period, however, immoderate use of chemicals exert a detrimental effect on soil fertility and lead to a decrease in crop productivity. Moreover, the effectiveness of these fungicides remains for a stunted time during the croping season (Akram and Anjum, 2011). Plant growth-promoting bacteria were used to maintain the biogeochemical cycle of soil and helps to induce anti-oxidant property against reactive oxygen species (ROS) - used for detoxification against biotic and abiotic stress.

The present investigation aimed to ascertain the effect of $M$. luteus on the induction of defense enzymes in the presence and the absence of Fusarium in chickpea plant. Yellow pigmented actinobacterial strain M. luteus was previously isolated from the marine environment and used as a talc-based bio- elicitor to induce plant defense under pot trials. Further, induced defense mechanisms were studied against Fusarium by enhancement of defense enzymes and markers like SOD, POX, L-proline, and total phenolic in chickpea. Chlorophyll and carotenoid content were also assessed in plants that were treated with M. luteus as compared to FOC treated plants.

\section{MATERIAL AND METHODS}

\section{Isolation of Marine bacteria}

M. luteus strain (Accession No. JX679497) was isolated from the marine freshwater of Khambhat, Gujarat, India. M. luteus was inoculated on a nutrient agar plate and incubated for $37^{\circ} \mathrm{C}$ for 48 hours. The bacteria were analyzed by 
morphology such as colony shape, size, opacity, elevation, and pigment production as portrayed in Bergy's manual of bacteriology Volume V (Goodfellow et al., 2012).

\section{Pot Trials}

Preparation of talc-based bio-formulation

Adopting the method portrayed by Goswami et al., (2013), a talc-based bioformulation was prepared for $M$ luteus strain. Briefly, 48 hrs grown culture was mixed with sterilized talc base. Talcum powder was taken and its $\mathrm{pH}$ was neutralized by $15 \mathrm{gm}$ of $\mathrm{CaCO}_{3}$ per $\mathrm{kg}$ and $10 \mathrm{gm}$ per $\mathrm{kg}$ of $\mathrm{CMC}$ was used as carbon source. The formulation was autoclaved followed by drying before further use. The chickpea seeds were surface coated with bioformulation by overnight soaking.

\section{Treatment of Soil and Seed by talc-based formulation}

Seeds were treated with $70 \%$ ethanol and $\mathrm{HgCl}_{2}$ for two and three minutes, respectively, under gentle shaking and finally washed with sterile distilled water to remove excess $\mathrm{HgCl}_{2}$ to achieve surface sterilization. The talc-based bioformulation was blended with sterile soil $(0.5 \mathrm{gm}$ powder $/ \mathrm{kg}$ soil $)$, and seeds were surface coated with talc-based bio formulation (Table 1).

$\underline{\text { Table } 1 \text { Experimental set up for management of Fusarium wilt disease on chickpea by M. luteus. }}$

\begin{tabular}{lc}
\hline No. of repetitions & Three (3) \\
Season & January 2018 \\
Crop and variety & Hybrid Desi chickpea \\
No. of seeds per pot & Ten $(10)$ \\
Pot size & $11 \times 11 \mathrm{~cm}$ \\
Treatments & $4(\mathbf{T 1}$ - control; T2- M. luteus treated; T3 - FOC treated; T4 - M. luteus + FOC treated)
\end{tabular}

Applications

1. Seed + Soil application Seeds coated with bio-formulation $-1 \mathrm{ml}\left(10^{6} \mathrm{cfu} / \mathrm{ml}\right) / \mathrm{kg}$ before sowing; the soil is treated with bioformulation during sowing.
2. Seed application
Seeds coated with bio-formulation $-1 \mathrm{ml}\left(10^{6} \mathrm{cfu} / \mathrm{ml}\right) / \mathrm{kg}$ before sowing Watering As and when needed

Plant sample collection for biochemical analysis

Plants of four treatments and two applications were carefully uprooted. All the treated plants were pooled individually and rinsed under running tap water to strip off adhered soil and dust. Leaves and roots were homogenized in a respective buffer to perform biochemical analysis. Extracts were then subjected to centrifugation to get supernatant which was stored for further assay.

\section{Effect of M. luteus on plant stress markers}

\section{Estimation of Superoxide dismutase}

Superoxide dismutase (SOD) catalyzes the dismutation of the oxygen-derived free radicals resulted from abiotic stress to plants. The activity of SOD was determined by following the method of Beauchamp and Fridovich (1971). The superoxide mediated reduction of nitro blue tetrazolium (NBT) was inhibited in the presence of SOD. The unit activity of enzyme represented by the amount of enzyme required to achieve $50 \%$ inhibition of NBT reduction measured at 560 $\mathrm{nm}$. To derive specific activity (U.mg of protein $^{-1}$ ), protein concentration present in each plant sample was determined using the Bradford assay procedure.

\section{Estimation of Peroxidase}

The assay was performed using pyrogallol as a substrate molecule. In the presence of peroxidase (POX) pyrogallol converts to purpurogallin, a brown compund. The color intensity was estimated at $420 \mathrm{~nm}$, proportional to concentration of product formed, using a spectrophotometer (Shimadzu) (Kar and Mishra, 1976).

\section{Estimation of Total phenolic compounds}

Plant tissues were homogenized in methanol and the methanolic extract was separated and augmented with folin-ciocalteau reagent $(1 \mathrm{~N})$ to form a blue color mixture. To determine the concentration, the color intensity was measured using a spectrophotometer at $725 \mathrm{~nm}$ against Gallic acid as a standard. The concentration of phenolic was expressed as $\mu \mathrm{g}$ catechol.gm ${ }^{-1}$ of fresh tissue (Zieslin and Ben-Zaken, 1993).

\section{Estimation of L-Proline content}

Adopting the method of Bates et al., (1973), L-proline content present in the leaves and roots was determined. The red-colored formazan formed upon mixing of L-proline and ninhydrin mixed under acid condition, solubilized in toluene, and read using a spectrophotometer at 520nm against toluene blank. To derive the concentration of L-proline, the standard curve of L-proline was prepared in the range of 5 to $100 \mu \mathrm{g} \cdot \mathrm{ml}^{-1}$ concentrations.

\section{Extraction of Chlorophyll and Carotenoids}

Fresh plant leaves were homogenized in $80 \%$ acetone and centrifuged at $10000 \mathrm{xg}$ for $10 \mathrm{~min}$. The supernatant was collected and analyzed for chlorophyll-a, chlorophyll-b, and carotenoids content using a spectrophotometer (Sumanta, 2014).
Following formulas were applied for determining quantities of chlorophyll-a, chlorophyll-b, and carotenoids from absorption data of extract

$\mathrm{Ch}-\mathrm{a}=12.25 \mathrm{~A}_{663.2}-279 \mathrm{~A}_{646.8}$

Ch-b $=21.5 \mathrm{~A}_{6468}-5.1 \mathrm{~A}_{6632}$

$\mathrm{Cx}+\mathrm{c}=\left(1000 \mathrm{~A}_{470}-1.82 \mathrm{Ch}-\mathrm{a}-85.02 \mathrm{Ch}-\mathrm{b}\right) / 198$

\section{Statistical Analysis}

To determine the effect of bioformulation treatment on the growth of plants in the presence and absence of a pathogen, the data collected after the germination of plantlets from all four treatments were analyzed statistically applying one way ANOVA.

\section{RESULTS}

\section{Micrococcus luteus}

Isolated purified M. luteus (Accession No. JX679497) colonies were having small, round, shiny, convex, entire, opaque, and showed yellow pigmentation (Figure 1). M. luteus showed a gram-positive reaction with a coccoid microscopic structure.

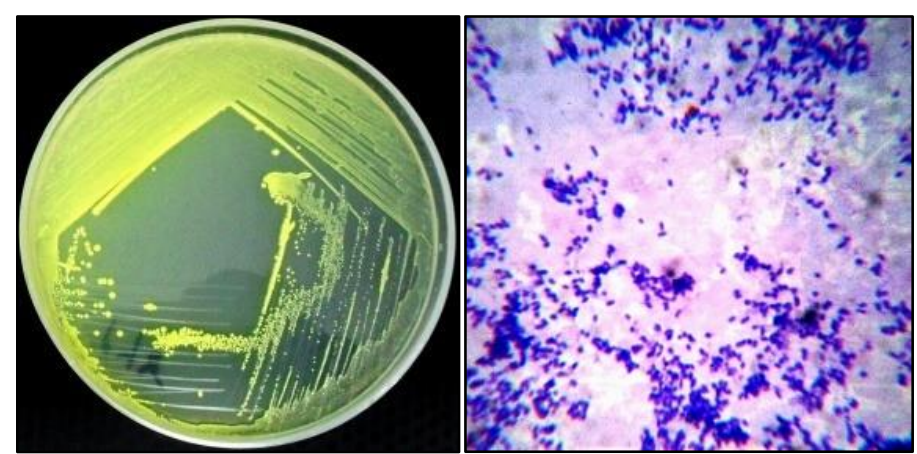

Figure 1 The Structural morphology of M. luteus on a nutrient agar plate and gram reaction showed a coccoid structure.

\section{Pot Study}

M. luteus treatment showed a significant increase in growth more in seed+soil application than talc-based bioformulation applied directly to seeds. $19 \%$ growth observed in seed+Soil application and 3\% growth in seed application while compared with pathogen treated and control plants after 20 days of sowing.

\section{Effect of M. luteus on plant stress markers}

\section{Estimation of SOD}

The significantly induced activity of plant defense enzymes like SOD in the roots was observed in the plants which that were treated with $M$. luteus as compared to other treatments. SOD constitutes the first line of defense against ROS, it acts as 
antioxidant enzymes due to the dismutation of $\mathrm{O}_{2}{ }^{-}$to $\mathrm{H}_{2} \mathrm{O}_{2}$. M. luteus treated plants showed maximum activity of SOD, $34.41 \%$ inhibition of $\mathrm{mg} \mathrm{protein}^{-1}$ in leaves and $72.14 \%$ inhibition of $\mathrm{mg}$ protein $^{-1}$ in roots in seed+ soil application (Figure 2A), while seed application showed $21.10 \%$ inhibition of $\mathrm{mg}$ of protein in leaves and $67.57 \%$ inhibition of $\mathrm{mg}$ protein $^{-1}$ in roots (Figure 2B). Enhanced SOD activity in chickpea suggests that $M$. luteus helps the plant to suppress the stress as the function of SOD is to neutralize free radicals.
A.

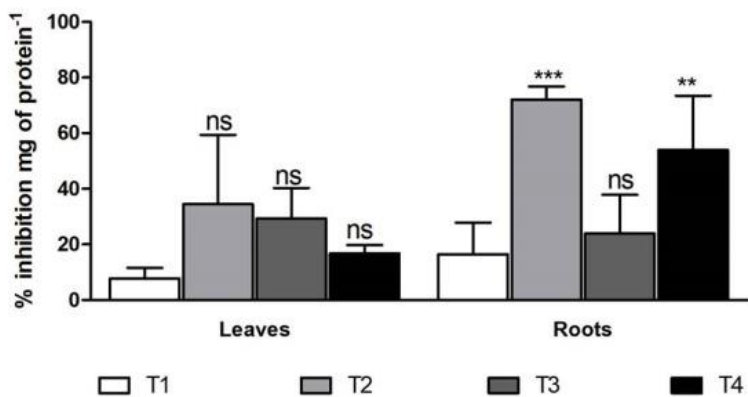

B.

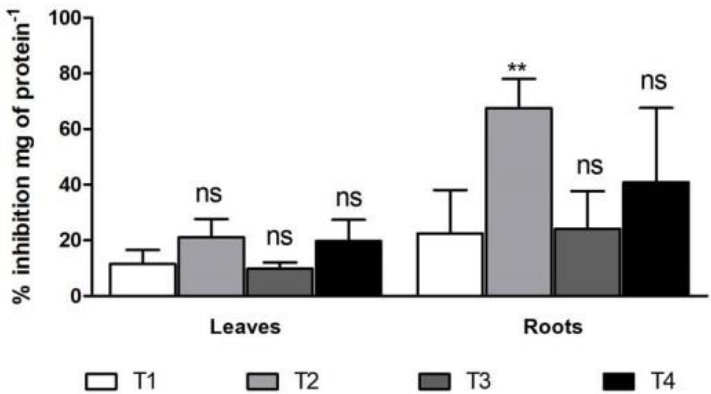

Figure 2 Estimation of superoxide dismutase from chickpea plant after applying four treatments in (a) seed + soil application (b) seed application. Where, T1: Control, T2: M.luteus treatment, T3: FOC infection, T4: FOC infection with M. luteus treatment Statistical significance was determined by Bonferroni t-test ('ns' Non-significant, '*' $\left.\mathrm{P}<0.05,{ }^{\prime * *} ’ \mathrm{P}<0.01,{ }^{\prime * * *}, \mathrm{P}<0.001\right)$

\section{Estimation of POX}

Elevated activity of plant defense enzymes like POX was observed in the plants which were treated with $M$. luteus as compared to other treatments. M. luteus treated plants showed maximum activity of POX, $1.018 \mathrm{U} . \mathrm{mg}$ protein ${ }^{-1}$ of

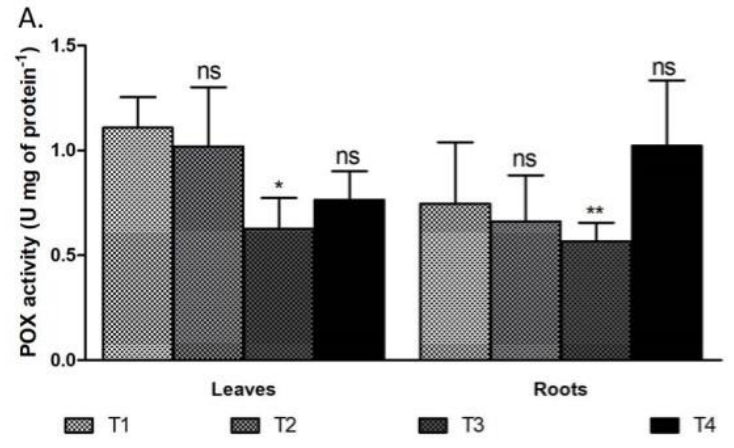

leaves, and $0.661 \mathrm{U} . \mathrm{mg}$ protein ${ }^{-1}$ of roots in seed+ soil application (Figure 3A) whereas, $0.464 \mathrm{U} . \mathrm{mg}$ protein ${ }^{-1}$ of leaves and $0.666 \mathrm{U}_{\mathrm{mg}}$ protein $^{-1}$ of roots in seed application (Figure 3B). It suggests that M. luteus helps the plant to protect itself from the free radicals as well as cell wall strengthening.

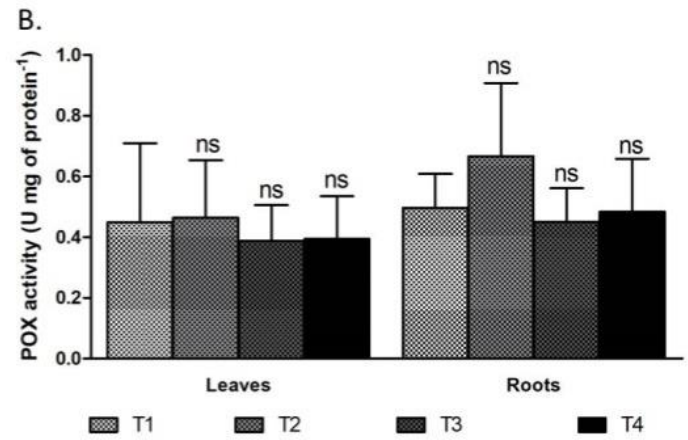

Figure 3 Estimation of peroxidase (POX) from chickpea plant after applying four treatments (A) seed + soil application (B) seed application. Statistical significance was determined by Bonferroni t-test ('ns' Non-significant, '*' $\mathrm{P}<0.05$, '**' $\mathrm{P}<0.01$, ' ${ }^{* * *}$ ' $\mathrm{P}<0.001$ )

\section{Estimation of L-proline content}

Accumulation of L-proline was observed in plants that were treated with $M$. luteus as compared to other treatments. M. luteus treated plants showed maximum accumulation, $0.962 \mu$ moles.gm ${ }^{-1}$ of fresh tissue of leaves, and 0.23

$\mu$ moles.gm ${ }^{-1}$ of fresh tissue of roots in seed + soil application (Figure $4 \mathrm{~A}$ ). While seed application showed $0.24 \mu$ moles.gm ${ }^{-1}$ of fresh tissue in leaves and 0.42 $\mu$ moles.gm ${ }^{-1}$ of fresh tissue in roots (Figure 4B).

A.

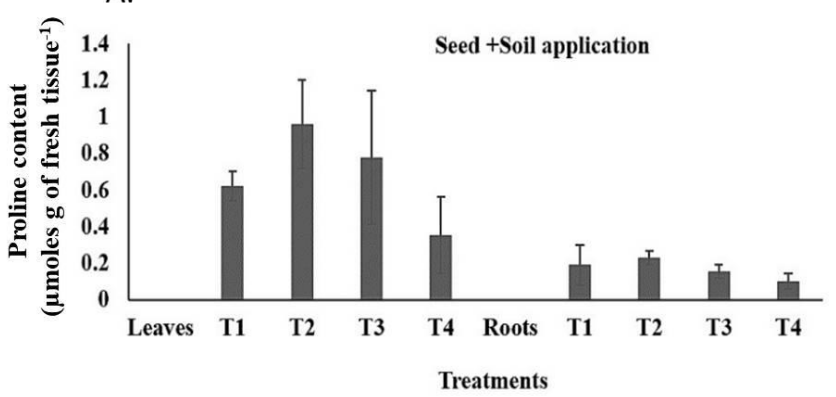

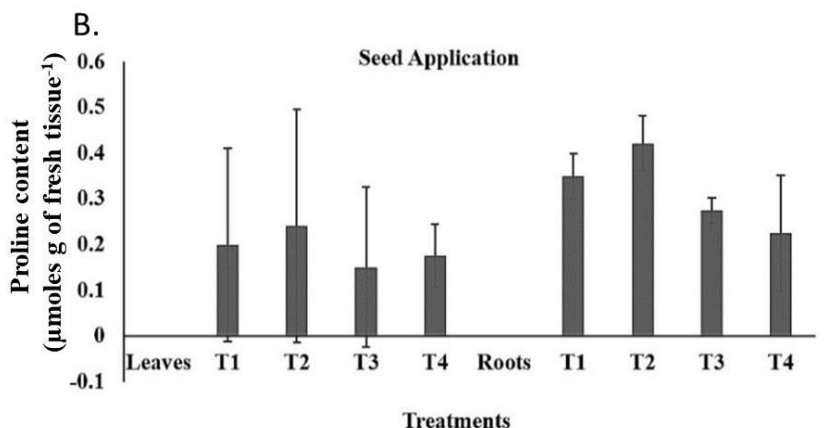

Treatments

Figure 4 Estimation of L-proline from chickpea plant after applying four treatments in (A) seed + soil application and (B) seed application

\section{Estimation of total phenolic compounds}

There was a significant increase in total phenolic content in the plant roots which were treated with $M$. luteus as compared to pathogen treated plant in seed+soil application. The maximum total phenolic content in seed+ soil application was
$0.058 \mathrm{mg}$ catechol.gm ${ }^{-1}$ of fresh tissue in leaves and $0.08 \mathrm{mg}^{\text {catechol.gm }}{ }^{-1}$ of fresh tissue in roots (Figure 5A). While seed application showed $0.081 \mathrm{mg}$ catechol.gm $\mathrm{gm}^{-1}$ of fresh tissue in leaves and $0.091 \mathrm{mg}$ catechol. $\mathrm{gm}^{-1}$ of fresh tissue in roots (Figure 5B). Increased phenolic activity by M. luteus signifies that it protect cellular components of plants in stress condition. 
A.

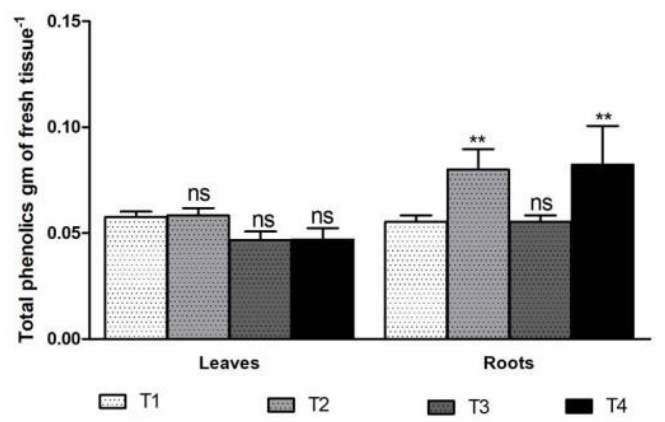

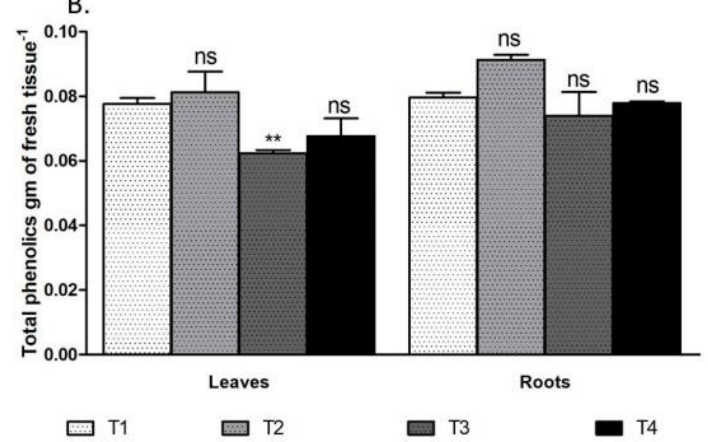

Figure 5 Estimation of total-phenolic compounds from chickpea plant after applying four treatments in (A) seed + soil application and (B) seed application. Statistical significance was determined by Bonferroni t-test ('ns' Non-significant, '*' $\mathrm{P}<0.05$, '**' $\mathrm{P}<0.01$, '***' $\mathrm{P}<0.001$ )

\section{Extraction of Chlorophyll and Carotenoids content}

Chlorophyll-a, chlorophyll-b, and carotenoids help in the photosynthesis process in plants and a small proportion of chlorophyll-a, chlorophyll-b is considered as sensitive biomarkers of pollution and environmental stress. M. luteus treated plants showed high content of chlorophyll-a $\left(167.1518 \mu \mathrm{g} \cdot \mathrm{ml}^{-1}\right)$, chlorophyll-b (6.3601 $\left.\mu \mathrm{g} \cdot \mathrm{ml}^{-1}\right)$ and carotenoids $\left(2.27 \mu \mathrm{g} \cdot \mathrm{ml}^{-1}\right)$ in seed + soil application and chlorophyll-a (378.22 $\left.\mu \mathrm{g} \cdot \mathrm{ml}^{-1}\right)$, chlorophyll-b $\left(17.65 \mu \mathrm{g} . \mathrm{ml}^{-1}\right)$ and carotenoids $\left(4.07 \mu \mathrm{g} . \mathrm{ml}^{-1}\right)$ in seed application as compared to pathogen treated plants (Table 2).

Table2 Extraction of chlorophyll and carotenoids from plants after seed + soil application and seed application

\begin{tabular}{|c|c|c|c|c|c|c|c|c|}
\hline \multirow[b]{2}{*}{ Pigments } & \multicolumn{4}{|c|}{ Seed +Soil application } & \multicolumn{4}{|c|}{ Seed application } \\
\hline & $\underset{\left(\mu \mathrm{g} \cdot \mathbf{m l}^{-1}\right)}{\text { T1 }}$ & $\begin{array}{c}\text { T2 } \\
\left(\mu \mathrm{g} \cdot \mathbf{m l}^{-1}\right)\end{array}$ & $\begin{array}{c}\text { T3 } \\
\left(\mu \mathrm{g} \cdot \mathbf{m l}^{-1}\right)\end{array}$ & $\begin{array}{c}\text { T4 } \\
\left(\mu \mathrm{g} \cdot \mathbf{m l}^{-1}\right)\end{array}$ & $\underset{\left(\mu \mathrm{g} \cdot \mathrm{ml}^{-1}\right)}{\mathrm{T})}$ & $\begin{array}{c}\text { T2 } \\
\left(\mu \mathrm{g} \cdot \mathbf{m l}^{-1}\right)\end{array}$ & $\begin{array}{c}\text { T3 } \\
\left(\mu \mathrm{g} \cdot \mathbf{m l}^{-1}\right)\end{array}$ & $\begin{array}{c}\text { T4 } \\
\left(\mu \mathrm{g} \cdot \mathbf{m l}^{-1}\right)\end{array}$ \\
\hline Chlorophyll- a & $150.9 \pm 17.5$ & $152.3 \pm 22.6$ & $77.24 \pm 60.1$ & $168.4 \pm 128.2$ & $338.2 \pm 85.97$ & $360.3 \pm 20.00$ & $275.9 \pm 30.66$ & $342.6 \pm 74.83$ \\
\hline Chlorophyll- b & $5.67 \pm 0.89$ & $6.021 \pm 0.39$ & $3.038 \pm 2.19$ & $9.411 \pm 8.40$ & $15.24 \pm 6.00$ & $16.47 \pm 1.33$ & $10.68 \pm 1.60$ & $15.48 \pm 5.20$ \\
\hline Carotenoids & $3.73 \pm 0.43$ & $4.10 \pm 2.03$ & $2.34 \pm 1.89$ & $2.36 \pm 1.89$ & $9.400 \pm 0.09$ & $9.941 \pm 1.11$ & $9.993 \pm 1.93$ & $9.211 \pm 0.50$ \\
\hline
\end{tabular}

\section{DISCUSSION}

After encountering the primary infection from pathogens, plants can generate immune response conferring protection to the entire plant known as systemic acquired resistance (SAR) (VanLoon et al., 1998). Plants can accumulate different types of small compounds, often called secondary metabolites. It has been reported that plants harbor an inherent capability of co-ordinated defense network of biochemical reactions, which are generally inducible required appropriate stimuli (Jones and Dangl, 2006). The present investigation assessed the elicitation capability of a marine $M$. luteus as talc-based bioformulation to stimulate systemic resistance in chickpea plant by provoking defense enzyme like superoxide dismutase, peroxidase, induction of total phenolic, accumulation of L-proline and extraction of pigments like carotenoids and chlorophyll against Fusarium. The rationale for preparing talc-based bioformulation was the ability of CMC present in the formulation act as a binding agent and allowed bacterial cells to adhere to the surface of the seed coat. Besides, talc-based bioformulation enhances the viability of bacterial cells by providing the environment and in turn, improves the shelf life of the biofertilizer. SOD, a metalloenzyme, constitute the first line of defense against ROS. The superoxide radicals are dismutated into hydrogen peroxide $\left(\mathrm{H}_{2} \mathrm{O}_{2}\right)$ and molecular oxygen $\left(\mathrm{O}_{2}\right)$ by SOD and consequently bestow an important defense mechanism against the toxicity of superoxide radicals. In the present study, we have found enhanced SOD activity in plant treated with $M$. luteus, in turn, helps plants to fight in stress condition because SOD is an illustrious antioxidant enzyme accumulates during any type of stress in plants to counter oxidative stress. Besides upon challenge by pathogens, two enzymes involved in phenylpropanoid biosynthetic pathway, peroxidase, and polyphenol oxidase, enhances the lignification of the plant cell wall and triggered hypersensitive response. According to Ali et al. (2011), POX is the enzyme that neutralizes the free radicals generated due to stress in the plant. In this study, we found an increase in POX activity in M. luteus treated plants. Phenolic compounds are secondary metabolites that possess the antioxidant property and they are adequately present in plant tissues (Bartwal et al., 2013). Besides, the formation of phenolic compound plays role in contributing enhance lignification of the plant cell wall to create a physical barrier as well as have a direct inhibitory effect on fungal pathogens (Karthikeyan et al., 2005; Thakker et al., 2013). In the present study, we found there was an increase in total phenolic content in the plants treated with $M$. Luteus which may help plants to detoxify ROS and protect themself and their cell organelles. Similar observations reported by Konappa $\boldsymbol{e}$ al., (2014), that tomato plants treated with Trichoderma asperellum isolates were able to significantly induce defense enzyme activity. Increased activity of phenols was observed in $T$. asperellum pretreated tomato seedlings challenged with $R$. solanacearum. Similarly, the induction of phenolics and defense enzymes were displayed by challenging plants with plant growth-promoting rhizobacteria Serratia marcescenes NBRI1213 by Lavania et al. (2006). Chlorophyll-a, chlorophyll-b, and carotenoids help in the photosynthesis process and a small proportion of chlorophyll $\mathrm{a} / \mathrm{b}$ is considered as a sensitive biomarker of pollution and environmental stress (Thalwale et al., 2011). In the present study, M. luteus treated plants showed high content of the pigments like chlorophyll-a, chlorophyll-b, and carotenoids in both seed + soil and in seed application which clarify that chlorophyll-a and chlorophyll-b indirectly help plants in attaining growth and carotenoids might help in plants defense by detoxifying ROS. The observations are in corroboration with Bartwal et al. (2013), who reported that carotenoids, a group of lipophilic antioxidants, capable of detoxifying various forms of ROS. John et al. (2010) reported that chlorophyll content in plant treated with Pythium arrhenomanes increases as compared to Fusarium treated plant and carotenoid content in plants treated with $P$. arrhenomanes decreases as compared to plant treated with fusarium. Proline is generally accumulated under salt stress or drought stress and it may also get accumulated in some type of biotic stress too. Proline maintains structures of cells and buffering cell redox potential under stress conditions.

There is a strong relationship between the accumulation of proline and stress experienced by the plants. More the stress experienced by plants greater the amount of proline accumulate. Hence, proline could be used as a stress marker Proline exhibit three main functions, as a metal chelator, an antioxidative defense, and a signaling molecule. While experiencing the stress conditions by plant proportionally proline concentration increase. These over produced proline in turn, imparts stress tolerance through maintaining turgor pressure by balancing osmotic pressure, stabilizing membrane resulted in prevention of electrolyte leakage, and help to reduce ROS concentration to normal range, which ultimately prevents oxidative burst in the plant (Hayat et al., 2012). In this study, we found a maximum accumulation of L-proline in M. luteus treated plants which may help plants under stress conditions to protect themselves from pathogens. Applications of biological elicitors, dead or alive, are reported to boost resistance response in several important crop plants (Sarvanan et al., 2004; Thakker et al., 2007; Thakker et al., 2011). This indicates that one of the plant's protection strategies could be the prior application of biological inducer that can successfully induce plant defense mechanisms even in the absence of pathogen (Siddiqui $\boldsymbol{e t}$ al. 2009).

\section{CONCLUSION}

The present investigation reveals the role of a marine Micrococcus luteus as an elicitor which induces defense in chickpea plants which can aid in plant protection against a fungal pathogen Fusarium oxysporum f.sp. ciceris.

Acknowledgments: We are thankful to the Department of Biotechnology (DBT) for the fellowship and financial support under project no. [BT/PR10877/AAQ/3/668/2014]. The authors are also thankful to Charotar University of Science and Technology (CHARUSAT) management to provide necessary facilities. 


\section{REFERENCES}

Akram, W., \& Anjum, T. (2011). Use of bioagents and synthetic chemicals for induction of systemic resistance in tomato against diseases. Int. Res. J. Agric. Sci. Soil Sci, 1, 286-292.

Ali, S. Z., Sandhya, V., Grover, M., Linga, V. R., \& Bandi, V. (2011). Effect of inoculation with a thermotolerant plant growth promoting Pseudomonas putida strain AKMP7 on growth of wheat (Triticum spp.) under heat stress. Journal of Plant Interactions, 6(4), 239-246. https://doi.org/10.1080/17429145.2010.545147 Bartwal, A., Mall, R., Lohani, P., Guru, S. K., \& Arora, S. (2013). Role of secondary metabolites and brassinosteroids in plant defense against environmental stresses. Journal of plant growth regulation, 32(1), 216-232. https://doi.org/10.1007/s00344-012-9272-x

Bates, L. S., Waldren, R. P., \& Teare, I. D. (1973). Rapid determination of free proline for water-stress studies. Plant and soil, 39(1), 205-207.

https://doi.org/10.1007/BF00018060

Beauchamp, C., \& Fridovich, I. (1971). Superoxide dismutase: improved assays and an assay applicable to acrylamide gels. Analytical biochemistry, 44(1), 276287. https://doi.org/10.1016/0003-2697(71)90370-8

Cunnington, J., Lindbeck, K., \& Jones, R. H. (2007). National Diagnostic Protocol for the Detection of Fusarium Wilt of Chickpea ( Fusarium Oxysporum f. sp. ciceris). Plant Health Australia, Camberra, Australia.

Datta, J., \& Lal, N. (2012). Temporal and spatial changes in phenolic compounds in response Fusarium wilt in chickpea and pigeonpea. Cell. Mol. Biol, 58(1), 96 102. https:// doi.org/10.1170/T926

Dehgahi, R., Subramaniam, S., Zakaria, L., Joniyas, A., Firouzjahi, F. B., Haghnama, K., \& Razinataj, M. (2015). Review of research on fungal pathogen attack and plant defense mechanism against pathogen. Int J Sci Res Agric Sci, 2, 197-208. https://dx.doi.org/10.12983/ijsras-2015-p0197-0208

Gaur, P. M., Jukanti, A. K., \& Varshney, R. K. (2012). Impact of genomic technologies on chickpea breeding strategies. Agronomy, 2(3), 199-221. https://doi.org/10.3390/agronomy2030199

Goswami, D., Vaghela, H., Parmar, S., Dhandhukia, P., \& Thakker, J. N. (2013) Plant growth promoting potentials of Pseudomonas spp. strain OG isolated from marine water. Journal of plant interactions, 8(4), 281-290. https://doi.org/10.1080/17429145.2013.768360

Hayat, S., Hayat, Q., Alyemeni, M. N., Wani, A. S., Pichtel, J., \& Ahmad, A (2012). Role of proline under changing environments: a review. Plant signaling \& behavior, 7(11), 1456-1466. https://doi.org/10.4161/psb.21949

John, R. P., Tyagi, R. D., Prévost, D., Brar, S. K., Pouleur, S., \& Surampalli, R. Y. (2010). Mycoparasitic Trichoderma viride as a biocontrol agent against Fusarium oxysporum f. sp. adzuki and Pythium arrhenomanes and as a growth promoter of soybean. Crop Protection, 29(12), $1452-1459$. https://doi.org/10.1016/j.cropro.2010.08.004

Jones, J. D., \& Dangl, J. L. (2006). The plant immune system. nature, 444(7117), 323. https://doi.org/10.1038/nature05286

Kar, M., \& Mishra, D. (1976). Catalase, peroxidase, and polyphenoloxidase activities during rice leaf senescence. Plant Physiology,57(2), 315-319. https://doi.org/10.1104/pp.57.2.315

Karthikeyan, M., Jayakumar, V., Radhika, K., Bhaskaran, R., Velazhahan, R., \& Alice, D. (2005). Induction of resistance in host against the infection of leaf blight pathogen (Alternaria palandui) in onion (Allium cepa var aggregatum).

Kavino, M., Kumar, N., Damodaran, T., Harish, S., \& Saravanakumar, D. (2009). Biochemical markers as a useful tool for the early identification of Fusarium oxysporum f. sp. cubense, race 1 resistance banana clones. Archives of Phytopathology and Plant Protection, 42(11), 1069-1078. https://doi.org/10.1080/03235400701622089

Kloepper, J. W. (1978). Plant growth-promoting rhizobacteria on radishes. In Proc. of the 4th Internet. Conf. on Plant Pathogenic Bacter, Station de Pathologie Vegetale et Phytobacteriologie, INRA, Angers, France, 1978 (Vol. 2, pp. 879-882)

Lavania, M., Chauhan, P. S., Chauhan, S. V. S., Singh, H. B., \& Nautiyal, C. S (2006). Induction of plant defense enzymes and phenolics by treatment with plant growth-promoting rhizobacteria Serratia marcescens NBRI1213. Current microbiology, 52(5), 363-368. https://doi.org/10.1007/s00284-005-5578-2

Saravanan, T., Bhaskaran, R., \& Muthusamy, M. (2004). Pseudomonas fluorescens induced enzymological changes in banana roots (Cv. Rasthali) against Fusarium wilt disease. Plant Pathology Journal, 3(2), 72-80.

Siddiqui, Z. A., Qureshi, A., \& Akhtar, M. S. (2009). Biocontrol of root-knot nematode Meloidogyne incognita by Pseudomonas and Bacillus isolates on Pisum sativum. Archives of Phytopathology and Plant Protection, 42(12), 11541164. https://doi.org/10.1080/03235400701650890

Singh, S., Singh, I., Kapoor, K., Gaur, P.M., Chaturvedi, S.K., Singh, N.P., Sandhu, J.S. (2014). Chickpea in Broadening the Genetic Base of Grain Legumes. National Bureau of Plant Genetic Resources. New Delhi, India.

Singha, I. M., Kakoty, Y., Unni, B. G., Kalita, M. C., Das, J., Naglot, A., ... \& Singh, L. (2011). Control of Fusarium wilt of tomato caused by Fusarium oxysporum $\mathrm{f}$. $\mathrm{sp}$. lycopersici using leaf extract of Piper betle L.: a preliminary study. World Journal of Microbiology and Biotechnology,27(11), 2583. https://doi.org/10.1007/s11274-011-0730-6
Sumanta, N., Haque, C. I., Nishika, J., \& Suprakash, R. (2014) Spectrophotometric analysis of chlorophylls and carotenoids from commonly grown fern species by using various extracting solvents. Research Journal of Chemical Sciences ISSN, 2231, 606X. https://doi.org/10.1055/s-0033-1340072

Swarupa, V., Ravishankar, K. V., \& Rekha, A. (2014). Plant defense response against Fusarium oxysporum and strategies to develop tolerant genotypes in banana. Planta, 239(4), 735-751. https://doi.org/10.1007/s00425-013-2024-8

Tahsili, J., Sharifi, M., Safaie, N., Esmaeilzadeh-Bahabadi, S., \& Behmanesh, M (2014). Induction of lignans and phenolic compounds in cell culture of Linum album by culture filtrate of Fusarium graminearum. Journal of plant interactions, 9(1), 412-417. https://doi.org/10.1080/17429145.2013.846419

Thakker, J. N., Patel, N., \& Kothari, I. L. (2007). Fusarium oxysporum derived elicitor-induced changes in enzymes of banana leaves against wilt disease. $J$ Mycol Plant Pathol, 37, 510-513. Thakker, J. N., Patel, P., \& Dhandhukia, P. C. (2011). Induction of defence-related enzymes in susceptible variety of banana: role of Fusarium-derived elicitors. Archives of phytopathology and plant protection, 44(20), 1976-1984. https://doi.org/10.1080/03235408.2011.559032

Thakker, J. N., Patel, S., \& Dhandhukia, P. C. (2013). Induction of defenserelated enzymes in banana plants: Effect of live and dead pathogenic strain of Fusarium oxysporum f. sp. cubense. International Scholarly Research Notices Biotechnology, 2013, Article id 601303, 1-6. http://dx.doi.org/10.5402/2013/601303

Thawale, P. R., Babu, S. S., Wakode, R. R., Singh, S. K., Kumar, S., \& Juwarkar, A. A. (2011). Biochemical changes in plant leaves as a biomarker of pollution due to anthropogenic activity. Environmental monitoring and assessment, 177(14), 527-535. https://doi.org/10.1007/s10661-010-1653-7

Van Loon, L. C. (1997). Induced resistance in plants and the role of pathogenesis-related proteins. European journal of plant pathology, 103(9), 753765. https://doi.org/10.1023/A:1008638109140

Zieslin, N., \& Ben Zaken, R. (1993). Peroxidase activity and presence of phenolic substances in peduncles of rose flowers. Plant Physiology and Biochemistry (France). 